Gut, 1989, 30, 906-911

\title{
Interaction of campylobacter species with antibody, complement and phagocytes
}

\author{
E BERNATOWSKA*, P JOSE, H DAVIES, M STEPHENSON, \\ AND D WEBSTER \\ From the Division of Immunological Medicine, Section of Electron Microscopy, Division of Communicable \\ Diseases, Division of Vascular Biology, Clinical Research Centre, Harrow, Middlesex
}

SUMMARY The opsonisation of four different campylobacter species for human neutrophils was studied using a chemiluminescence system and electron microscopy. Opsonisation of Campylobacter fetus, Campylobacter coli, and Campylobacter jejuni was mediated by antibody and enhanced by complement. Antibody was not, however, required for the phagocytosis of Campylobacter pylori because it activates the classical pathway of complement directly. This unusual property may be important in the pathogenesis of $C$ pylori associated gastritis and duodenal ulcer.

The past decade has seen a rapid expansion in our knowledge of the role of campylobacter species in human disease. Campylobacter jejuni (and less frequently Campylobacter coli) is a common cause of self-limiting diarrhoea in normal subjects ${ }^{12}$ and chronic diarrhoea in patients with hypogammaglobulinaemia. ${ }^{3}$ Campylobacter fetus, although more often causing septicaemia in immunocompromised hosts ${ }^{4}$ chronic alcoholics and other patients with lowered resistance ${ }^{56}$ may also be found in the stools of patients with diarrhoea. ${ }^{7}$ Campylobacter pylori colonises the gastric mucosa of most patients with gastritis and/or duodenal ulcer and is probably involved in the inflammatory process. ${ }^{89}$

Our interest in the gut flora of hypogammaglobulinaemic patients prompted us to study the opsonisation of campylobacter species for neutrophil phagocytosis, with the aim of determining whether antibody is critically required. We found that $C$ pylori had some unusual properties which may help explain its association with gastritis.

\section{Methods}

CAMPYLOBACTER SPECIES

The following species were used; two strains of Campylobacter jejuni, one from Dr Newell, Public

Address for correspondence: Dr A D B Webster, CRC, Watford Road, Harrow, Middlesex HA1 3UJ.

*Present address: Centrum Zdrowia Dziecka, Pomnik-Szpital, Warsaw, Poland. Accepted for publication 29 November 1988.
Health Laboratory, Southampton (NCTC 11828), and the other from Northwick Park Hospital (NCTC 11626); both isolated from patients with diarrhoea; Campylobacter coli (NCTC 11353); Campylobacter fetus (NCTC 10842), and a strain (DU74-Northwick Park) of Campylobacter pylori isolated from gastric antral biopsy tissue taken from a patient with duodenal ulcer. This has similar growth, morphological and antigenic characteristics to the NCTC 11639 strain of $C$ pylori.

The organisms were grown microaerobically at $37^{\circ} \mathrm{C}$ on blood agar with columbia agar base and $10 \%$ horse blood. The medium was freshly prepared for the growth of Campylobacter pylori and routinely contained $100 \mathrm{IU} / \mathrm{ml}$ of nystatin.

After one to three days growth, the organisms were harvested into phosphate buffered saline (PBS), washed twice in PBS and finally suspended at an opacity matched by eye to 10 international opacity units (equivalent to about $5 \times 10^{9} / \mathrm{ml}$ total organisms in PBS). The organisms were stored in aliquots at $-70^{\circ} \mathrm{C}$ until required.

\section{SERA}

Fresh sera were obtained from laboratory workers and frozen at $-70^{\circ} \mathrm{C}$ within one hour. Where stated, complement was inactivated by heating the sera at $56^{\circ} \mathrm{C}$ for 30 minutes. Serum was also obtained from a patient with homozygous $\mathrm{C} 2$ deficiency and from a patient with severe hypogammaglobulinaemia (IgG $<100 \mathrm{mg} / 100 \mathrm{ml}, \mathrm{IgA}$ and $\mathrm{IgM}<10 \mathrm{mg} / 100 \mathrm{ml}$ ). 
Pooled gammaglobulin for intravenous use (Gamimune - Cutter) was dialysed to remove stabilising sugars, and adjusted to a concentration of $30 \mathrm{~g} / \mathrm{l}$ in PBS.

\section{ANTIBODY ASSAYS}

Campylobacter species at $5 \times 10^{9}$ organisms $/ \mathrm{ml}$ in PBS, harvested and washed as above, were further diluted 1:750 (found to be the optimal dilution previously) in PBS and killed by heating at $60^{\circ} \mathrm{C}$ for one hour. Microwell plates were coated with $100 \mu \mathrm{l}$ of the bacterial suspension for two hours at $37^{\circ} \mathrm{C}$. After three washes with PBS containing $0.5 \%$ Tween $20,100 \mu \mathrm{l}$ serum diluted 1:10 in PBS was added in quadruplicate. Background wells were treated with PBS only. After incubation at $37^{\circ} \mathrm{C}$ for two hours, the plates were washed three times with PBS/Tween; 50 $\mu \mathrm{l}$ of 1:1000 dilution of class specific IgG peroxidase conjugated anti human immunoglobulin (No A-3150 Sigma) was added and the plate incubated overnight at $4^{\circ} \mathrm{C}$. After three further washes with PBS/Tween, $100 \mu \mathrm{l}$ of diethanolamine buffer ( $\mathrm{pH} 9.5)$ with $5 \mathrm{mg} /$ $\mathrm{ml}$ substrate colour indicator was added. The plates were incubated at room temperature for 30 minutes and then read on an automated ELISA reader.

\section{CHEMILUMINESCENCE ASSAY}

The uptake of bacteria by neutrophils (opsonisation) and phagocytosis was measured by chemiluminescence..$^{10}$ Briefly, neutrophils were separated from the venous blood of normal volunteers by dextran sedimentation, followed by hypotonic water lysis to remove red cells. The neutrophils were dispensed in aliquots in $1 \mathrm{ml}$ Hanks buffered salt solution containing Hepes ( $\mathrm{pH} 7 \cdot 4)$ and luminol $\left(10^{-5} \mathrm{M}\right)$ at a concentration of $2 \times 10^{6} / \mathrm{ml}$. In most experiments, 100 $\mu l$ of live (not heated) campylobacter suspension was added with $25 \mu \mathrm{l}$ of various sera, and the chemiluminescence measured over 10 minutes in a LKB luminometer.

\section{ELECTRON MICROSCOPY}

After 10 minutes exposure to organisms, neutrophils were fixed in suspension for one hour by adding an equal volume of $6 \%$ glutaraldehyde in $0.1 \mathrm{M}$ sodium cacodylate with $5 \%$ sucrose, $\mathrm{pH} 7 \cdot 4$. They were post-fixed in osmium tetroxide in $0.1 \mathrm{M}$ sodium cacodylate, dehydrated and finally embedded in Spurr resin. Ultra-thin sections were stained with uranyl acetate and lead citrate and then examined in a JEOL 1200EX electron microscope.

ACTIVATION OF C3

Complement activation was monitored by use of a competitive binding radioimmunoassay for the $\mathrm{C} 3$ cleavage product, C3a and its more stable des Arg metabolite. Sera ( $25 \mu \mathrm{l}$ in $1 \mathrm{ml}$ hepes buffered Hanks solution) were incubated at $37^{\circ} \mathrm{C}$ with $100 \mu \mathrm{l}$ Campylobacter pylori, Mycoplasma hominis as a positive control ${ }^{11}$ or PBS as a negative control. Activation was terminated by the addition of sodium EDTA pH $7.4\left(10^{-2} \mathrm{M}\right.$, final concentration). After centrifugation the supernatants were stored at $-25^{\circ} \mathrm{C}$ for assay. Residual C3 (which cross-reacts with the anti-C3a antibody) was removed by precipitation with an equal volume of polyethylene glycol 6000 $(22 \%)$ containing protamine sulphate $(1 \%)$. The radioimmunoassay method was modified from Jose $e t$ al. ${ }^{12}$ Briefly, $100 \mu$ l supernatant, or purified C3a for the standard, was incubated for 16 hours with $50 \mu \mathrm{l}$ ${ }^{125} \mathrm{I}$-human C3a (2.0 ng; approx $\left.30 \mathrm{nCi}\right)$ and $100 \mu \mathrm{l}$ rabbit anti-human $\mathrm{C} 3 \mathrm{a}$ (diluted 1/22000). Antibody bound material was precipitated by an excess of protein-A bacterial adsorbent (Sigma) and radioactivity determined on a multiwell gamma spectrometer. C3a concentrations were calculated by use of a spline fit programme.

We checked that the sera used had normal levels of activatable $\mathrm{C} 3$ by incubating serum $(100 \mu \mathrm{l})$ with zymosan $(500 \mu \mathrm{g})$ for one hour at $37^{\circ} \mathrm{C}$. The agammaglobulinaemic and the $\mathrm{C} 2$ deficient sera generated 101 and $63 \mu \mathrm{g} / \mathrm{ml}$ of C3a respectively.

\section{Results}

\section{ANTIBODY ASSAYS}

Healthy laboratory workers were screened for antibody to the various campylobacters to identify positive sera for use in the chemiluminescence assays. One of these had a high titre on ELISA to all the campylobacters except $C$ pylori and her serum was used for the experiments referred to in Figure 1 (Table). High titre serum to $C$ pylori was obtained from a laboratory worker with a chronic duodenal ulcer.

OPSONISATION

Figure 1 shows the chemiluminescence released from

Table Antibodies (IgG) to Campylobacter species in sera used for experiments

\begin{tabular}{llll}
\hline & $\begin{array}{l}\text { Normal } \\
\text { serum }\end{array}$ & $\begin{array}{l}\text { C2 } \\
\text { serum }\end{array}$ & $\begin{array}{l}\text { Pooled gammaglobulin } \\
\text { (Gamimune) }\end{array}$ \\
\hline C jejuni (11828) & $5 \cdot 4^{*}$ & $2 \cdot 3$ & $6 \cdot 0(5 \mathrm{mg} / \mathrm{ml})$ \\
C jejuni (11626) & $4 \cdot 3$ & $2 \cdot 5$ & \\
C coli & $4 \cdot 1$ & $1 \cdot 6$ & \\
C fetus & $2 \cdot 8$ & $1 \cdot 3$ & \\
C pylori & $11 \cdot 5$ & $3 \cdot 1$ & \\
\hline
\end{tabular}

*The figures are fold increases over background (optical density) measured by ELISA. The data can only be used to compare the levels for individual isolates in the sera and gammaglobulin. 

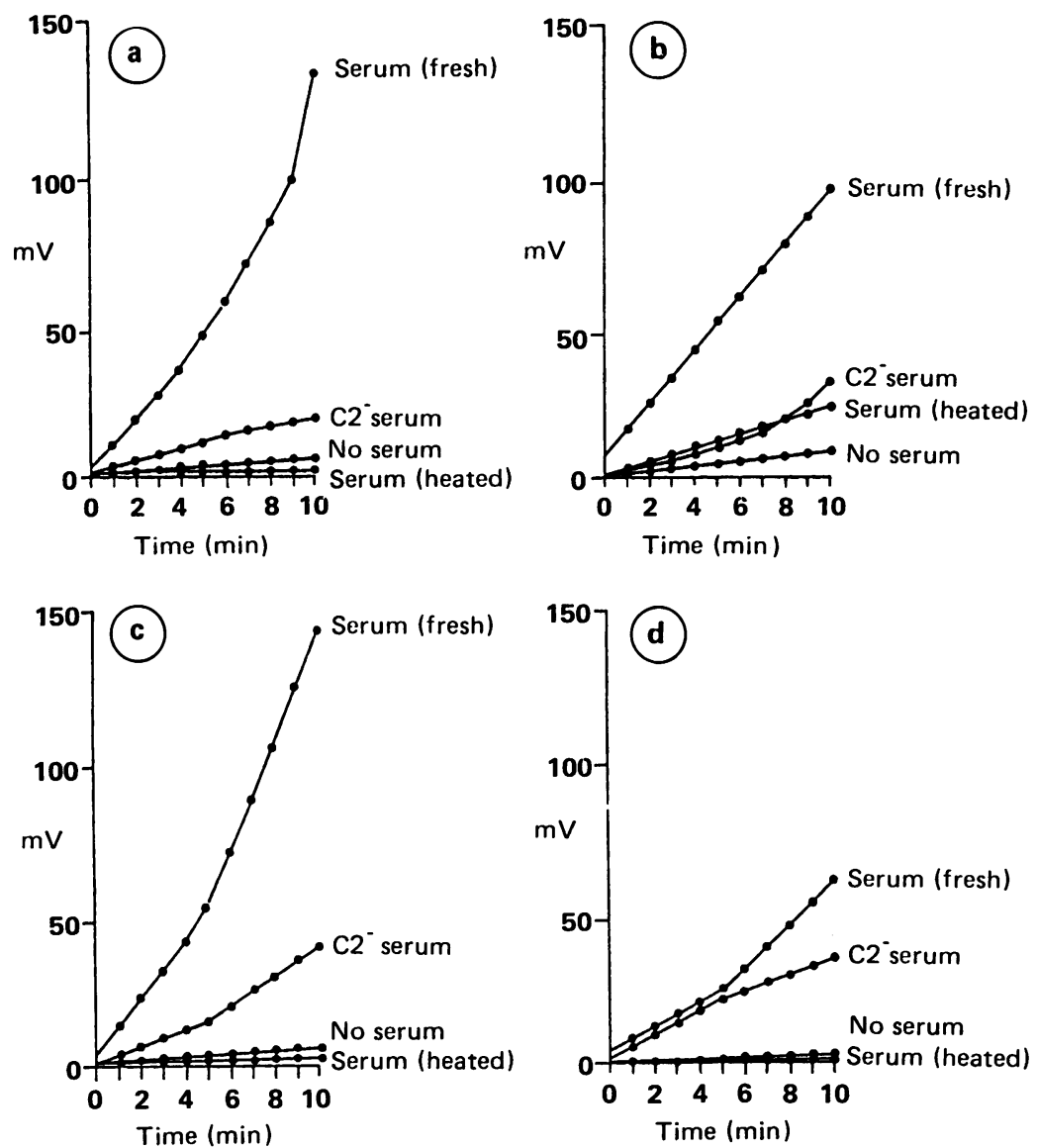

Fig. 1 Chemiluminescence assays (measured in $\mathrm{mV}$ against time) with normal neutrophils. $C 2^{-}=$serum from patient with homozygous $\mathrm{C} 2$ deficiency. Serum (heated) at $56^{\circ} \mathrm{C} 30$ min. (a) Campylobacter jejuni (NCTC 11828), (b) Campylobacter jejuni (NCTC 11626), (c) Campylobacter coli (NCTC 11353), (d) Campylobacter fetus (NCTC 10842).

normal neutrophils with the campylobacter species associated with large bowel disease. All showed a similar pattern with fresh serum promoting a marked rise in chemiluminescence, and very little reaction with heat inactivated (decomplemented) serum. The normal fresh serum used for Campylobacter jejuni (Fig. 1a) was known to contain antibody by ELISA, implying that complement was necessary for significant opsonisation in this system. Low but significant chemiluminescence occurred, however, with the $\mathrm{C} 2$ deficient serum which also contained some antibody, suggesting that either antibody alone or activation through the alternative pathway can affect binding, albeit inefficiently. Fresh agammaglobulinaemic serum did not opsonise (not shown), implying that these organisms are not capable of activating complement in the absence of antibody. Pooled IgG containing measurable antibody to Campylobacter jejuni did induce significant chemiluminescence, indicating that some IgG antibodies are effective opsonins in their own right; fresh agammaglobulinaemic serum, as a source of complement, enhanced the chemiluminescence (Fig. 2).

Campylobacter pylori induced no significant increase in chemiluminescence in the absence of opsonins, but this was markedly enhanced by the addition of fresh agammaglobulinaemic serum as a source of complement, and was further increased by the addition of serum containing specific antibody (Fig. 3). Electron microscopy of neutrophils at the end of this assay showed many bacteria within phagocytic vacuoles (Fig. 4).

\section{C3A GENERATION}

The ability of $C$ pylori to induce neutrophil chemiluminescence in the presence of agammaglobulinaemic serum prompted us to investigate the interaction of this organism with complement. 


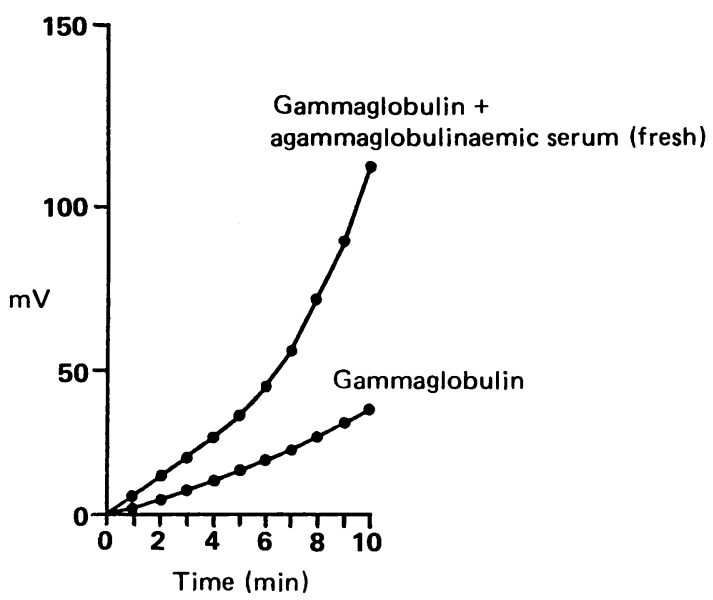

Fig. 2 Chemiluminescence release by normal neutrophils with Campylobacter jejuni (11828) and a pooled gammaglobulin ( $\mathrm{IgG}$ ) concentrate (final concentration $5 \mathrm{mg}$ / $\mathrm{ml}$ ), with and without agammaglobulinaemic serum (final concentration $25 \mu \mathrm{l} / \mathrm{ml}$ ) as a complement source.

Figure 5 shows that $C$ pylori rapidly generates $\mathrm{C} 3 \mathrm{a}$ from agammaglobulinaemic fresh serum, but not from C2 deficient serum. As both these sera had adequate concentrations of activatable C3 (see Methods), the activation of $C$ pylori appears to be mediated through the classical pathway. The enzymatic cleavage of serum C3 normally leads to the production of $\mathrm{C} 5 \mathrm{a}$ and this was confirmed in an experiment, where $805 \mathrm{ng}$ of C5a was generated from fresh agammaglobulinaemic serum by $C$ pylori with only a background of $4 \mathrm{ng}$ from the serum alone.

\section{Discussion}

Campylobacters have been found on the mucosal surfaces of the stomach, small and large intestine, and Campylobacter jejuni is clearly a cause of mucosal inflammation and diarrhoea. ${ }^{2}$ The mechanism of the mucosal damage is not understood, and the possible role of toxin is being explored. ${ }^{13}$ Bacteria are rarely seen penetrating the mucosal surface, although superficial ulceration in the large bowel may occur in immunodeficient patients with chronic Campylobacter jejuni enteritis. ${ }^{14}$ As with many other intestinal organisms, secretory IgA antibody may be an important protective mechanism, ${ }^{15}$ although recurrent campylobacter enteritis does not feature as a common complication in surveys of IgA deficient patients. ${ }^{16}$ Patients who lack all classes of antibodies, however, are prone to Campylobacter jejuni enteritis, suggesting that IgG and/or IgM antibodies may be important.

A cause and effect relationship between Campylobacter pylori, gastritis and duodenal ulcer is now

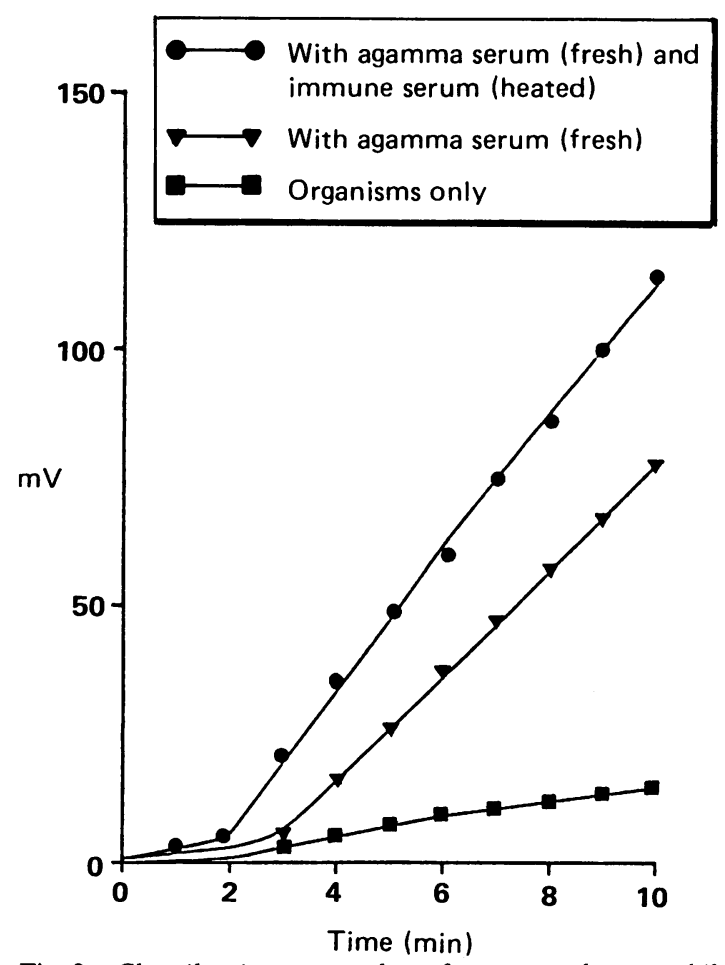

Fig. 3 Chemiluminescence release from normal neutrophils with Campylobacter pylori. Sera were added at $25 \mu \mathrm{l} / \mathrm{ml}$ of neutrophil suspension.

accepted by most workers, mainly because of the very high healing rates achieved with bismuth and antibiotics, ${ }^{8}$ and the occurrence of gastritis after drinking concentrates of $C$ pylori by volunteers. ${ }^{17}$ The mechanism of $C$ pylori induced inflammation is not understood, however, and there is no explanation for the apparent tropism of the organism for gastric epithelium.

The organisms are found beneath the mucus layer of the stomach, lying on the surface of mucosal cells; invading organisms are very rarely seen. ${ }^{18}$ We have shown that $C$ pylori will activate the classical complement pathway in the absence of antibody, generating both C3a and C5a. It is known that the local generation of $\mathrm{C} 3 \mathrm{a}$ and the neutrophil chemoattractant, C5a, can initiate inflammatory responses. By analogy with mycoplasmas, this process is probably initiated by direct activation of the first complement component (C1). " An unanswered question is whether there is enough complement on the mucosal surface to mediate these reactions. At all events, a small unrelated inflammatory focus might be enough to initiate the process, which would be selfperpetuating as the organisms multiplied and caused further inflammation. 


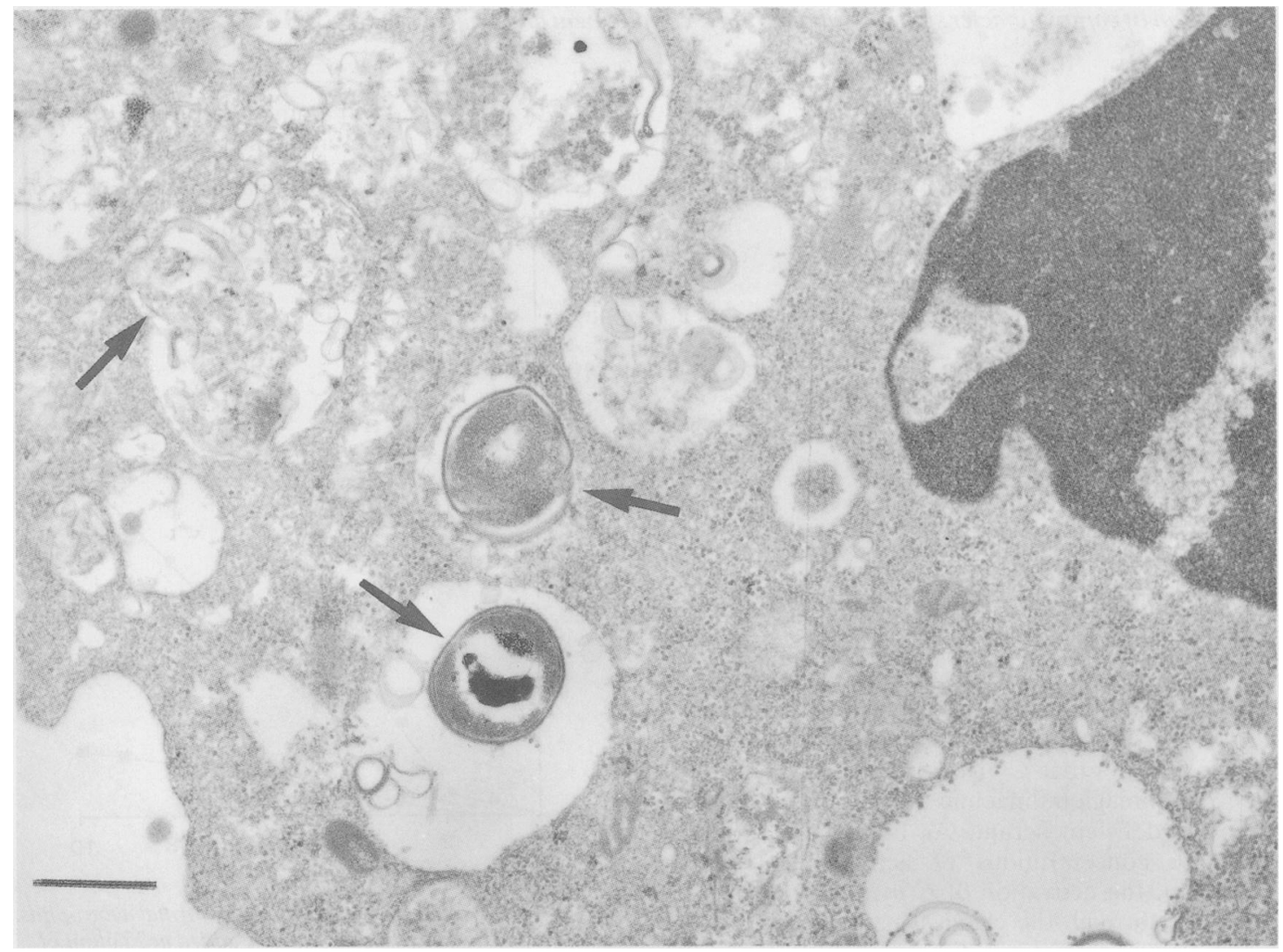

Fig. 4 Electron micrograph of neutrophils after 10 minutes incubation with agammaglobulinaemic serum (see Fig. 3). Note phagocytic vacuoles containing $\mathrm{C}$ pylori organisms (arrows), some of which are virtually destroyed. $\mathrm{Bar}=0 \cdot 5 \mu \mathrm{m}$.

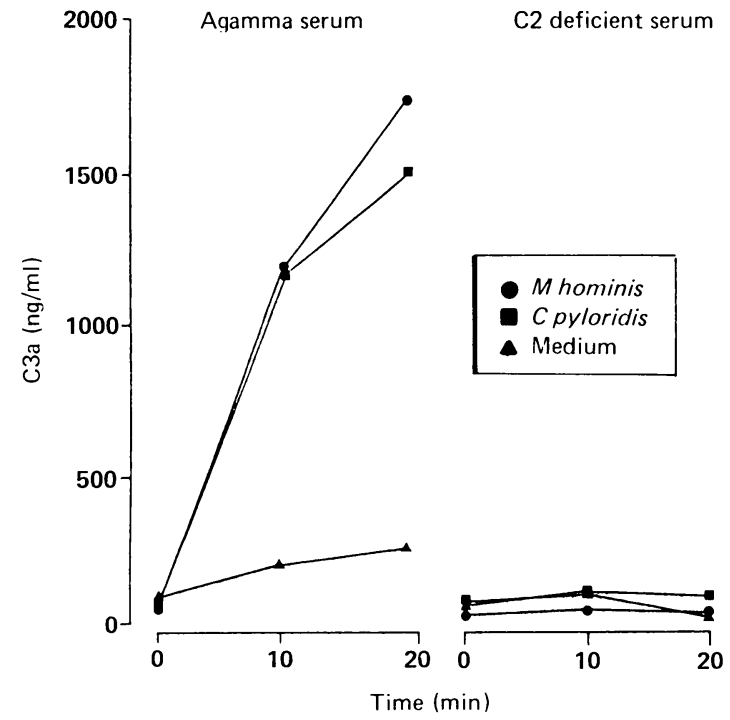

Fig. 5 Figure shows the generation of C 3 a from fresh agammaglobulinaemic and $C 2$ deficient serum by $\mathrm{C}$ pylori, $\mathrm{M}$ hominis and medium alone after 10 and 20 minutes incubation.
Specific antibodies, which are raised in patients with $C$ pylori gastritis, appear to have no relevance to either protection or resolution of the infection, because patients with chronic gastritis have high levels of both serum and local antibody. ${ }^{19}$ Furthermore, patients with severe hypogammaglobulinaemia are not prone to symptomatic gastritis or duodenal ulcer (A D B Webster - unpublished).

In conclusion, we have shown that four different campylobacter species associated with large and small bowel infection are opsonised for neutrophil phagocytosis by a combination of antibody and complement in serum. Thus, the growth of these organisms is probably controlled by local antibodies in the mucosa, explaining why they commonly infect patients with hypogammaglobulinaemia. In contrast, C pylori activates complement directly, a property which may explain why it is associated with both chronic and acute inflammation in the gastric mucosa, sometimes with massive protein loss, ${ }^{21}$ without invading the surface. Identifying the molecular structure of the component which activates complement, presumably located in the bacterial cell wall, 
may lead to the development of therapeutically active compounds which block this reaction.

We are grateful to Dr J Dolby for encouragement and help in formulating the project, and to Daphne Bird and Dr A Hassan for technical assistance.

\section{References}

1 Skirrow MB. Campylobacter enteritis. Br Med J 1977; 2: 9-11.

2 Blaser MJ, Reller LB. Campylobacter enteritis. $N$ Engl J Med 1981; 305: 1444-52.

3 Ahnen DJ, Brown WR. Campylobacter enteritis in immune-deficient patients. Ann Intern Med 1982; 96: 187-8.

4 Righter J, Woodrow AW, Hart GD, McNeely DJ. Relapsing septicaemia caused by Campylobacter fetus subsp fetus. Can Med Assoc J 1983; 128: 686-9.

5 Targan SR, Chow AW, Guze LB. Spontaneous peritonitis in cirrhosis due to Campylobacter fetus. Gastroenterology 1976; 11: 311-4.

6 Guerrant RL, Lahita RG, Winn WC, Roberts RB. Campylobacteriosis in Man: Pathogenic mechanisms and review of 91 bloodstream infections. Am J Med 1978; 65: 584-92.

7 Riley LW, Finch MJ. Results of the first year of National Surveillance of Campylobacter infections in the United States. J Infect Dis 1985; 151: 956-9.

8 Rauws EAJ, Langenberg W, Houthoff HJ, Zanen HC, Tytgat GNJ. Campylobacter pyloridis - associated chronic active antral gastritis. A prospective study of its prevalence and the effects of antibacterial and antiulcer treatment. Gastroenterology 1988; 94: 33-40.

9 Marshall BJ, Warren JR. Unidentified curved bacilli on gastric epithelium in active chronic gastritis. Lancet 1983; i: $1273-5$.
10 Lever AML. Gross J. Webster ADB. Serum factors for opsonisation of non-typeable Haemophilus influenzac. J Med Microbiol 1985; 20: 33-8.

11 Webster ADB. Furr PM. Hughes-Jones NC. Gorick BD. Taylor-Robinson D. Critical dependence on antibody for defence against mycoplasmas. Clin Exp Immunol 1988; 71: 383-7.

12 Jose PJ. Forrest MJ, Williams TJ. Detection of the complement fragment C.5a in inflammatory exudates from the rabbit peritoneal cavity using radioimmunoassay. J Exp Med 1983; 158: 2177-82.

13 Klipstein FA, Engert RF. Short H. Schenk EA. Pathogenic properties of Campylobacter jejuni: Assay and correlation with clinical manifestations. Infect Immun 1985; 50: 43-9.

14 Lever AML, Dolby JM, Webster ADB, Price AB. Chronic campylobacter colitis and uveitis in patients with hypogammaglobulinacmia. $\mathrm{Br}$ Med $J$ 1984; 288: 531 .

15 Hanson LA, Ahlstedt S, Andersson B, et al. The biologic properties of secretory IgA. J Reticuloendothel Soc 1980; 28 [suppl]: 1-10.

16 Burks AW, Stecle RW. Selective IgA deficiency. Ann Allergy 1986; 57: 3-13.

17 Marshall BJ, Armstrong JA, McGechic DB, Glancy RJ. Attempt to fulfil Koch's postulates for pyloric campylobacter. Med J Austr 1985; 142: 436-9.

18 Johnston BJ, Reed PI, Ali MH. Campylobacter-like organisms in duodenal and antral endoscopic biopsies: relationship to inflammation. Gut 1986; 27: 1132-7.

19 Wyatt J, Rathbone BJ, Heatley RV. Local immune response to gastric Campylobacter in non-ulcer dyspepsia. J Clin Pathol 1986; 39: 863-70.

20 Hill ID, Sinclair-Smith C, Lastovica AJ, Bowie MD, Emms M. Transient protein losing enteropathy associated with acute gastritis and Campylobacter pylori. Arch Dis Child 1987; 62: 1215-9. 